\title{
Role of K-Opioid Receptors in the Bed Nucleus of Stria Terminalis in Reinstatement of Alcohol Seeking
}

\author{
AD Lê ${ }^{1,2,3}$, Douglas Funk ${ }^{*, 1}$, Kathleen Coen', Sahar Tamadon' and Yavin Shaham ${ }^{4}$ \\ 'Neurobiology of Alcohol Laboratory, Campbell Family Mental Health Research Institute, Centre for Addiction and Mental Health, Toronto, ON, \\ Canada; ${ }^{2}$ Department of Pharmacology and Toxicology, University of Toronto, Toronto, ON, Canada; ${ }^{3}$ Department of Psychiatry, University of \\ Toronto, Toronto, ON, Canada; ${ }^{4}$ Behavioral Neuroscience Branch, Intramural Research Program, NIDA-NIH, Baltimore, MD, USA
}

\begin{abstract}
$\kappa$-Opioid receptors (KORs) and their endogenous ligand dynorphin are involved in stress-induced alcohol seeking but the mechanisms involved are largely unknown. We previously showed that systemic injections of the KOR agonist U50,488, which induce stress-like aversive states, reinstate alcohol seeking after extinction of the alcohol-reinforced responding. Here, we used the neuronal activity marker Fos and site-specific injections of the KOR antagonist nor-BNI and U50,488 to study brain mechanisms of U50,488-induced reinstatement of alcohol seeking. We trained male Long-Evans rats to self-administer alcohol ( $12 \% \mathrm{w} / \mathrm{v})$ for $23-30$ days. After extinction of the alcoholreinforced responding, we tested the effect of $U 50,488(0,1.25,2.5$, and $5 \mathrm{mg} / \mathrm{kg})$ on reinstatement of alcohol seeking. Next, we correlated regional Fos expression with reinstatement induced by the most effective U50,488 dose ( $5 \mathrm{mg} / \mathrm{kg}$ ). Based on the correlational Fos results, we determined the effect of bed nucleus of the stria terminalis (BNST) injections of nor-BNI (4 $\mu \mathrm{g} /$ side) on U50,488-induced reinstatement of alcohol seeking, and reinstatement induced by injections of U50,488 (0, 0.3, I, and $3 \mu \mathrm{g} / \mathrm{side})$ into the BNST. U50,488induced reinstatement of alcohol seeking was associated with increased Fos expression in multiple brain areas, including the BNST, where it was significantly correlated with lever pressing. U50,488-induced reinstatement was blocked by BNST nor-BNI injections, and BNST U50,488 injections partially mimicked the drug's systemic effect on reinstatement. Our data indicate that the BNST is a critical site for U50,488-induced reinstatement of alcohol seeking and suggest that KOR/dynorphin mechanisms in this brain area play a key role in stressinduced alcohol seeking.
\end{abstract}

Neuropsychopharmacology (2018) 43, 838-850; doi:10.1038/npp.2017.120; published online 12 July 2017

\section{INTRODUCTION}

Stress is associated with heavy alcohol use and relapse (Brown et al, 1995; Sinha and Li, 2007). Over the past two decades, we and others have used the reinstatement model (Shaham et al, 2003) to study the role of different brain areas and neurotransmitter systems in stress-induced relapse to alcohol seeking in rats and mice (Le and Shaham, 2002; Mantsch et al, 2016), including the $\kappa$-opioid receptor (KOR)/dynorphin system (Bruchas et al, 2010).

The KOR/dynorphin system plays a critical role in stress responses (Van't Veer and Carlezon, 2013). Acute stress stimulates the release of dynorphin in brain areas involved in emotion, motivation, and drug seeking, including the bed nucleus of the stria terminalis (BNST) and amygdala (Bruchas et al, 2010; Morley et al, 1982; Nabeshima et al, 1992), and chronic stress exposure causes long-lasting effects on KOR function (Karkhanis et al, 2016). In addition, KOR

\footnotetext{
*Correspondence: Dr D Funk, Neurobiology of Alcohol Laboratory, Campbell Family Mental Health Research Institute, Centre for Addiction and Mental Health, 33 Russell Street, Toronto, ON M5S 2SI, Canada, Tel: + | 416535850 I ×3675I, Fax: + | 4165956922 ,

E-mail: Douglas.Funk@camh.ca

Received 9 February 20 17; revised 31 May 20 17; accepted I June 2017; accepted article preview online 7 June 2017
}

agonists induce conditioned place aversion (CPA) and depression- and anxiety-like states, whereas KOR antagonists induce anxiolytic and antidepressant effects in animal models (Bechara and van der Kooy, 1987; Falcon et al, 2015; Land et al, 2008, 2009; Mague et al, 2003; Mucha and Herz, 1985; Pliakas et al, 2001; Privette and Terrian, 1995).

The KOR/dynorphin system also plays a role in the effect of stressors and withdrawal states on drug selfadministration and reinstatement of drug seeking (Bruchas et al, 2010). Stress-induced increases in alcohol drinking are not observed in dynorphin knockout mice (Sperling et al, 2010). KOR antagonists decrease stress-induced reinstatement of cocaine and nicotine seeking and preference (Beardsley et al, 2005, 2010; Jackson et al, 2012; Redila and Chavkin, 2008), and stress-induced potentiation of cocaine and alcohol conditioned place preference (CPP) (McLaughlin et al, 2006; Sperling et al, 2010). However, one study showed that systemic injections of the KOR antagonist JDTic had no effect on footshock-induced reinstatement of alcohol seeking (Schank et al, 2012). KOR antagonists also prevent increased alcohol intake induced by alcohol dependence (Walker and Koob, 2008; Walker et al, 2011), and escalation of heroin, cocaine, and methamphetamine self-administration (Schlosburg et al, 2013; Wee et al, 2009; Whitfield et al, 2015). 
In agreement with the above results, we found that systemic injections of the selective KOR agonist U50,488 reinstate nicotine and alcohol seeking in rats (Funk et al, 2014; Grella et al, 2014). These results extend earlier studies showing that KOR agonists reinstate cocaine seeking in squirrel monkeys (Valdez et al, 2007) and cocaine CPP in mice (Redila and Chavkin, 2008). The goal of our present study was to determine the brain sites involved in U50,488induced reinstatement of alcohol seeking. We first replicated the results of our previous study (Funk et al, 2014) by determining a dose-response curve for U50,488-induced reinstatement of alcohol seeking. We then used the neuronal activity marker Fos (Curran and Morgan, 1995) to determine U50,488-induced neuronal activation in different brain areas implicated in KOR/dynorphin-mediated stress responses and stress-induced reinstatement of drug seeking. These include dorsal and ventral medial prefrontal cortex (mPFC), orbitofrontal cortex (OFC), nucleus accumbens (NAc) core and shell, dorsal and ventral BNST (dBNST, vBNST), central and basolateral amygdala (CeA, BLA), lateral hypothalamus $(\mathrm{LH})$, dorsal and median raphe nuclei (DRN, MRN), and nucleus tractus solitarius (NTS) (Bossert et al, 2013; Bruchas et al, 2010; Mantsch et al, 2014, 2016; Van't Veer and Carlezon, 2013).

We found that in dorsal and ventral BNST, U50,488induced Fos expression was significantly correlated with lever pressing, a finding consistent with the role of the BNST in stress-induced drug seeking (Erb et al, 2001) and the role of BNST KOR/dynorphin in stress responses (Crowley et al, 2016). Based on the correlational Fos data, we determined the causal role of BNST KORs in U50,488-induced reinstatement using local injections of the selective KOR antagonist, nor-BNI (Portoghese et al, 1987). We also determined whether BNST U50,488 injections will mimic the drug's systemic effect on reinstatement of alcohol seeking.

\section{MATERIALS AND METHODS}

For subjects, drugs, apparatus, alcohol self-administration, extinction and reinstatement testing, food pellet self-administration, immunohistochemistry, cannula surgery and injections, and corticosterone radioimmunoassay, see Supplementary Material Online.

\section{Exp. 1: Effects of U50,488 on Reinstatement of Alcohol Seeking}

The goal of Exp. 1 was to determine the optimal dose for U50,488-induced reinstatement alcohol seeking for the subsequent Fos-mapping experiment (Exp. 2). We trained 13 rats to self-administer alcohol and then gave them daily extinction sessions until they reached the extinction criterion. We determined the effects of U50,488 on reinstatement using a within-subjects design with the factors of U50,488 Dose $(0,1.25,2.5$, and $5 \mathrm{mg} / \mathrm{kg}$, i.p.) and Lever (active, inactive). We injected each rat with vehicle or one of the doses of U50,488 and 30 min later placed them in selfadministration chambers for a 60 min reinstatement test. We gave the doses in counterbalanced order with at least 2 days of regular extinction sessions between tests.
Exp. 2: Effects of U50,488 on Reinstatement of Alcohol Seeking: Correlation with Fos Expression

The goal of Exp. 2 was to determine whether U50,488induced reinstatement of alcohol seeking is associated with increased neuronal activity in different brain areas implicated in KOR/dynorphin-mediated stress responses and stress-induced reinstatement of alcohol seeking. We trained 32 rats to self-administer alcohol and then gave them daily extinction sessions until they reached the extinction criterion. We determined the effects of U50,488 on reinstatement of alcohol seeking using a mixed-design with the between factor of U50,488 Dose (vehicle, $5 \mathrm{mg} / \mathrm{kg}$, i.p.) and within factor of Lever (active, inactive), and on Fos expression using a between-subjects design with the factor of $\mathrm{U} 50,488$ dose. We injected each rat with vehicle $(n=8)$ or $\mathrm{U} 50,488(n=24)$, and $30 \mathrm{~min}$ later placed them in the selfadministration chambers for a 60 min reinstatement test. At the end of the test, we anesthetized them with sodium pentobarbital, perfused them, and processed their brains for Fos immunohistochemistry. We used a larger number of rats in the drug condition to ensure sufficient statistical power to detect statistically significant correlations between lever presses during testing and Fos expression induced by U50,488 injections.

\section{Exp. 3: Effects of Intra-BNST Nor-BNI on U50,488-Induced Reinstatement}

In Exp. 2 we found that of the different brain areas under study, Fos expression in the BNST was significantly correlated with the active lever pressing induced by U50,488 during the reinstatement tests. The goal of Exp. 3 was to determine whether BNST KORs mediate U50,488induced reinstatement of alcohol seeking by injecting the selective KOR antagonist nor-BNI into the BNST before the reinstatement tests. We trained 22 rats to self-administer alcohol and then implanted them with bilateral cannulas aimed at the BNST. After 1 week of recovery, we gave them 4 more daily alcohol self-administration sessions, and then daily extinction sessions until they reached the extinction criterion. We determined the effect of BNST nor-BNI on U50,488-induced reinstatement using a mixed-factorial design with the between-subjects factor of nor-BNI Dose $(0,4 \mu \mathrm{g} /$ side $)$ and the within-subject factors of U50,488 Dose (0, $5 \mathrm{mg} / \mathrm{kg}$, i.p.) and Lever (active, inactive). We injected each rat with vehicle or nor-BNI into the BNST and $15 \mathrm{~min}$ later injected them with vehicle or U50,488. After $30 \mathrm{~min}$, we placed the rats in the self-administration chambers for a $60 \mathrm{~min}$ reinstatement test. We performed the two reinstatement tests 2-3 days apart and gave the rats regular extinction sessions on the intervening days.

\section{Exp. 4: Effects of BNST U50,488 on Reinstatement of Alcohol Seeking}

In Exp. 3 we found that nor-BNI BNST injections blocked U50,488-induced reinstatement, demonstrating the necessity of BNST KORs in the systemic effect of U50,488 on reinstatement. The goal of Exp. 4 was to determine the sufficiency of activation of BNST KORs in inducing reinstatement. To test this idea, we determined whether 
BNST injections of U50,488 would mimic the drug's systemic effect on reinstatement. We trained 12 rats to selfadminister alcohol and then implanted them with bilateral cannulas aimed at the BNST. After 1 week of recovery, we gave them 4 additional daily alcohol self-administration sessions, and then daily extinction sessions until they reached the extinction criterion. We determined the effect of BNST U50,488 injections on reinstatement using a withinsubjects design with the factors of U50,488 Dose (0, 0.3, 1.0, and $3 \mu \mathrm{g} / \mathrm{side}$ ) and Lever (active, inactive). We injected each rat with vehicle or U50,488 into the BNST, and 5 min later, we placed the rats in the self-administration chambers for a 60 min reinstatement test. We performed the reinstatement tests 2-3 days apart and gave the rats regular extinction sessions on the intervening days.

\section{Exp. 5: Effects of Intra-BNST Nor-BNI on Responding for Food Pellets}

In Exp. 3 we found that BNST injections of nor-BNI blocked U50,488-induced reinstatement. The goal of Exp. 5 was to rule out the possibility that the effect of these injections on reinstatement is due to nonspecific motor deficits. For this purpose, we determined the effect of BNST nor-BNI injections on high-rate lever pressing for palatable food pellets (Calu et al, 2014). We implanted 12 rats with bilateral cannulas aimed at the BNST. After 1 week of recovery, we trained them to self-administer the food pellets (catalog no. 1811155, TestDiet). We gave the rats daily $1 \mathrm{~h}$ of selfadministration sessions under an FR-1 reinforcement schedule for 12 days. We then determined the effect of BNST nor-BNI injections on lever pressing for food pellets using a within-subjects design with the factors of nor-BNI Dose $(0,4 \mu \mathrm{g} /$ side $)$ and Lever (active, inactive). We injected each rat bilaterally with vehicle into the BNST and $45 \mathrm{~min}$ later placed the rats in the self-administration chambers for a $1 \mathrm{~h}$ food self-administration session. After 2 days, we injected the rats with nor-BNI into the BNST 45 min before a $1 \mathrm{~h}$ food self-administration session. We gave the rats a regular self-administration session on the day between the tests. We did not counterbalance the vehicle and nor-BNI injections to avoid a carryover effect of nor-BNI on lever presses from test 1 to test 2 .

\section{Exp. 6: Effect of U50,488 on Serum Corticosterone Levels}

The goal of Exp. 6 was to determine whether under our experimental conditions, the effective dose of U50,488 for

\begin{tabular}{|c|c|c|c|}
$\begin{array}{c}\text { Home-cage intermittent } \\
\text { alcohol access }\end{array}$ & $\begin{array}{c}\text { Alcohol self- } \\
\text { administration }\end{array}$ & Extinction & Reinstatement tests \\
\hline $30 \mathrm{~d}$ & $25 \mathrm{~d} \times 1 \mathrm{~h} / \mathrm{d}$ & $7 \mathrm{~d} \times 1 \mathrm{~h} / \mathrm{d}$ & $4 \mathrm{~d} \times 1 \mathrm{~h} / \mathrm{d}$
\end{tabular}

b

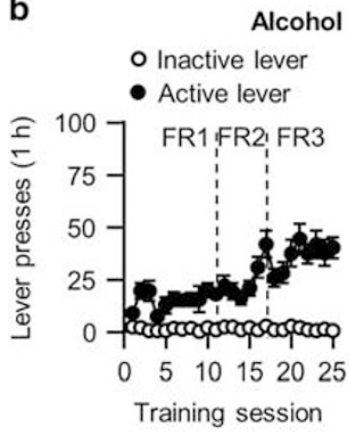

Alcohol self-administration

- Alcohol rewards $(0.19 \mathrm{ml})$

- Intake $(\mathrm{g} / \mathrm{kg})$

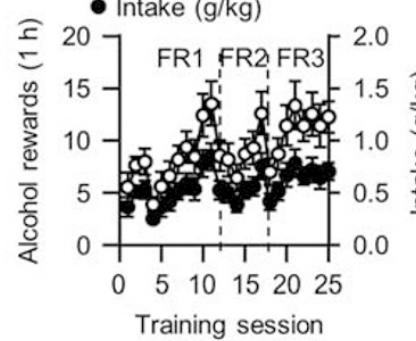

C

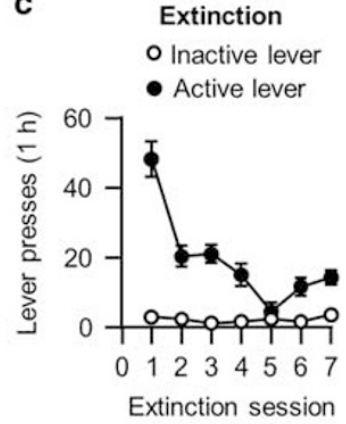

d

Reinstatement
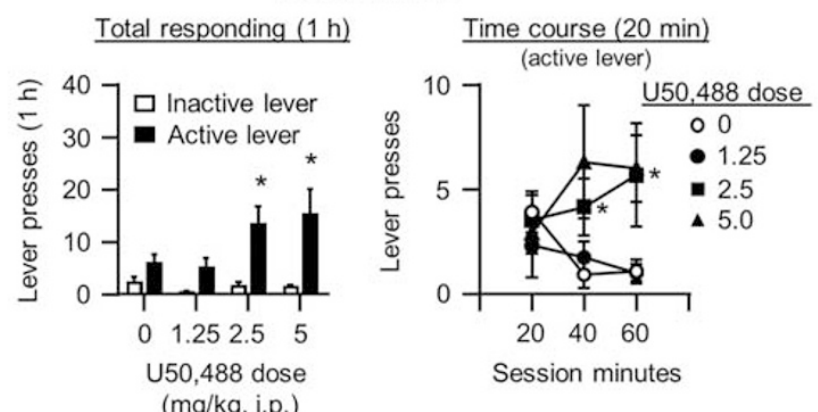

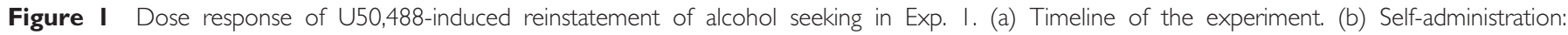

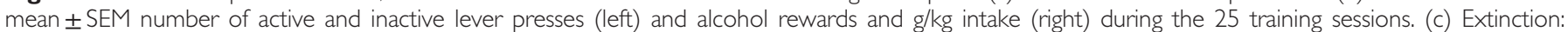

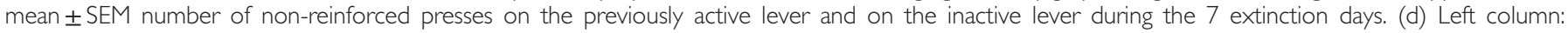

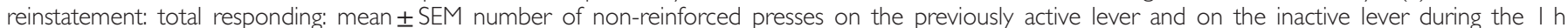

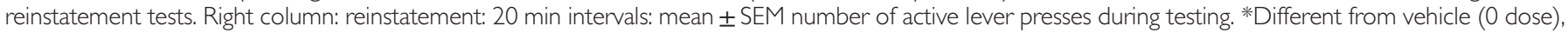
$p<0.05, n=13$. FR, fixed ratio, i.p., intraperitoneal. 
Timeline: Experiment 2

\begin{tabular}{|c|c|c|c|}
$\begin{array}{c}\text { Home-cage intermittent } \\
\text { alcohol access }\end{array}$ & $\begin{array}{c}\text { Alcohol self- } \\
\text { administration }\end{array}$ & Extinction & $\begin{array}{c}\text { Reinstatement } \\
\text { test, perfusion }\end{array}$ \\
\hline $25 \mathrm{~d}$ & $30 \mathrm{~d} \times 1 \mathrm{~h} / \mathrm{d}$ & $7 \mathrm{~d} \times 1 \mathrm{~h} / \mathrm{d}$ & $1 \mathrm{~d} \times 1 \mathrm{~h} / \mathrm{d}$
\end{tabular}

b

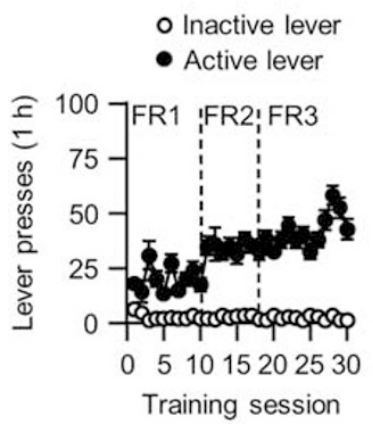

Alcohol self-administration

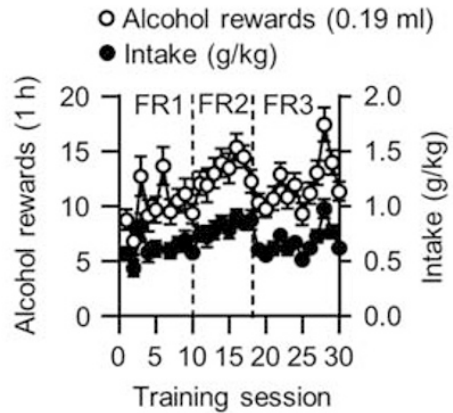

C

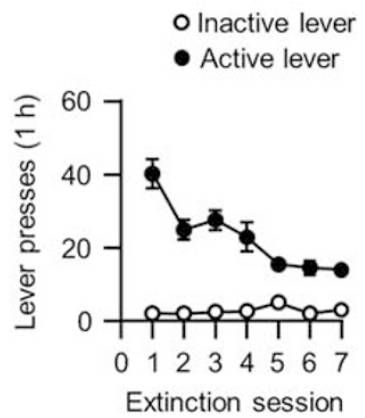

d

Reinstatement
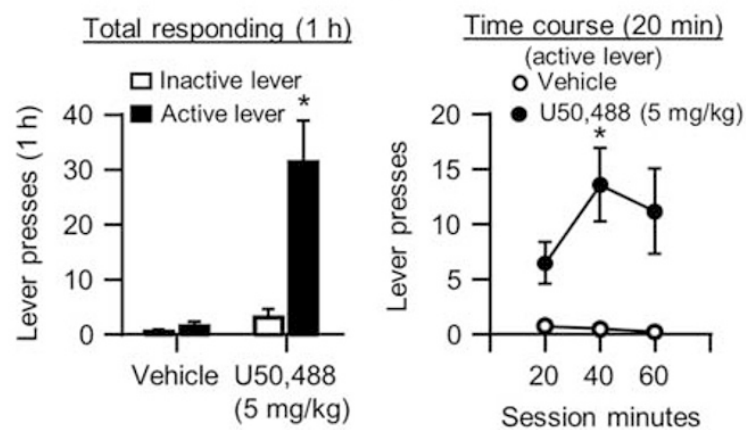

Figure 2 U50,488-induced reinstatement of alcohol seeking in Exp. 2. (a) Timeline of the experiment. (b) Self-administration: mean \pm SEM number of active and inactive lever presses (left) and alcohol rewards and g/kg intake (right) during the 30 training days. (c) Extinction: mean \pm SEM number of non-reinforced presses on the previously active lever and on the inactive lever during the 7 extinction days. (d) Left column: reinstatement: total responding: mean \pm SEM number of non-reinforced presses on the previously active lever and on the inactive lever during the I h reinstatement tests. Right column: reinstatement: 20 min intervals: mean \pm SEM number of active lever presses during testing. *Different from vehicle ( 0 dose), $p<0.05, v e h i c l e, n=8 ; ~ U 50,488$ (5 mg/ $/ \mathrm{kg})$, $n=24$.

reinstatement of alcohol seeking induces a physiological stress response, as assessed by measuring plasma levels of the stress hormone corticosterone (cortisol in humans) (Dallman et al, 1995; Selye, 1936). We gave 30 rats 5 daily vehicle injections (i.p.) and placed them in cages for $1 \mathrm{~h}$ to habituate them to the injection procedure. The following day, we injected them with U50,488 (5 mg/kg i.p.) and decapitated them either immediately $(0 \mathrm{~min})$ or 30 or $60 \mathrm{~min}$ after the injection ( $n=10$ per time point) and collected their trunk blood for corticosterone analysis. We used the $0 \mathrm{~min}$ time-point as the baseline, because we and others found that rats habituated to vehicle injections show negligible injection-induced corticosterone increase (Ignar and Kuhn, 1990; Marinelli et al, 2007).

\section{RESULTS}

\section{Systemic Injections of U50,488 Reinstate Alcohol Seeking after Extinction}

In Exp. 1 we determined the dose response of U50,488 on reinstatement of alcohol seeking (see Figure 1a for experimental timeline). As in our previous studies under similar training and extinction conditions (Le et al, 2005, 2006, 2011), the rats demonstrated reliable alcohol selfadministration $(\sim 0.7 \mathrm{~g} / \mathrm{kg}$ at the end of training) and extinction of the alcohol-reinforced responding when lever pressing was not reinforced with alcohol during the extinction phase (Figure $1 \mathrm{~b}$ and $\mathrm{c}$ ). During the subsequent reinstatement tests, systemic injections of U50,488 caused a dose-dependent increase in active but not inactive lever presses The ANOVA showed a significant interaction between U50,488 Dose and Lever $\left(\mathrm{F}_{3,33}=3.9, p=0.018\right)$. The post hoc analyses showed significant differences in vehicle versus $2.5 \mathrm{mg} / \mathrm{kg}(p=0.013)$ and $5 \mathrm{mg} / \mathrm{kg}(p=0.003)$ (Figure 1d). Figure 1d (right column) shows the time course of active lever presses (20 min intervals) during the reinstatement tests. The statistical analysis showed a significant interaction between U50,488 Dose and Lever $\left(\mathrm{F}_{3,33}=3.1, p=0.04\right)$. The post hoc group differences were observed between vehicle and $2.5 \mathrm{mg} / \mathrm{kg}$ at the $20-40 \mathrm{~min}$ interval $(p=0.013)$ and vehicle versus $5 \mathrm{mg} / \mathrm{kg}$ at the 40-60 min interval $(p=0.025)$. Together, the data in Exp. 1 show that systemic injections of U50,488 reinstate alcohol seeking in a dose-dependent manner. 


\section{U50,488-Induced Reinstatement of Alcohol Seeking Is Associated with Fos Induction in BNST}

In Exp. 2 we used the activity marker Fos to determine whether U50,488-induced reinstatement of alcohol seeking is associated with neuronal activation in different brain areas implicated in KOR/dynorphin-mediated stress responses and stress-induced reinstatement of alcohol seeking (see Figure 2a for experimental timeline).

Training, extinction, and reinstatement. As in Exp. 1, the rats demonstrated reliable alcohol self-administration, extinction of the alcohol-reinforced responding during the extinction phase, and robust U50,488-induced reinstatement (Figure 2b-d). As in Exp. 1, we observed reliable reinstatement of alcohol seeking after systemic injections of $5 \mathrm{mg} / \mathrm{kg}$ of U50,488, as indicated by a significant interaction between U50,488 Dose and Lever $\left(F_{1,29}=4.5, p=0.042\right)$. Figure $2 \mathrm{~d}$ (right column) shows the time course of active lever presses (20 min intervals) during the reinstatement tests. The statistical analysis showed a significant interaction between U50,488 Dose and Lever $\left(F_{1,30}=4.3, p=0.048\right)$. Significant post hoc group differences were observed between vehicle and U50,488 at the $20-40$ min interval $(p=0.031)$.

Fos expression and correlations between Fos expression and active lever presses. During the reinstatement tests, systemic injections of U50,488 (5 mg/kg) caused significant Fos induction in multiple brain areas (Figures $3 \mathrm{~d}$ and e and $4 \mathrm{~d}$ and e), including dorsal $\mathrm{mPFC}\left(\mathrm{F}_{1,29}=6.2, p=0.02\right)$, ventral $\operatorname{mPFC}\left(\mathrm{F}_{1,27}=15.4, p<0.001\right)$, OFC $\left(\mathrm{F}_{1,29}=6.9, p=0.01\right)$, NAc core $\left(\mathrm{F}_{1,28}=5.5, p=0.03\right)$, NAc shell $\left(\mathrm{F}_{1,28}=4.5\right.$, $p=0.04)$, dorsal BNST $\left(\mathrm{F}_{1,28}=5.2, p=0.03\right)$, ventral BNST $\left(\mathrm{F}_{1,29}=44.6, \quad p<0.001\right), \quad \mathrm{CeA} \quad\left(\mathrm{F}_{1,27}=7.5, \quad p=0.01\right), \quad \mathrm{LH}$ $\left(\mathrm{F}_{1,29}=26.3, p<0.001\right), \mathrm{DRN}\left(\mathrm{F}_{1,28}=21.5, p<0.001\right), \mathrm{MRN}$ $\left(\mathrm{F}_{1,29}=13.7, p<0.001\right)$, and NTS $\left(\mathrm{F}_{1,26}=6.0, p=0.02\right)$, but not BLA $(p>0.1)$. Subsequent Pearson's $r$ correlations between Fos-IR values and active lever presses during the reinstatement tests in rats injected with U50,488 $(n=24)$ showed significant correlations for dorsal BNST $(r=0.42, p=0.04)$ and ventral BNST $(r=0.43, p=0.03)$ but not the other brain areas (Figures 3f, 4f, and Supplementary Table 1).

Together, the data in Exp. 2 show that U50,488-induced reinstatement is associated with increased neuronal activity in multiple brain areas, and that neuronal activity in BNST but not in other brain areas is significantly correlated with this reinstatement.

\section{BNST Injections of Nor-BNI Blocked U50,488-Induced Reinstatement of Alcohol Seeking}

Based on the results of Exp. 2-significant correlations between U50,488-induced reinstatement of active lever presses and Fos induction in BNST-in Exp. 3, we tested the causal role of BNST KORs in U50,488-induced reinstatement of alcohol seeking by using site-specific injections of the KOR antagonist, nor-BNI (see Figure 5a for experimental timeline). As in Exp. 1-2, the rats demonstrated reliable alcohol selfadministration and extinction of the alcohol-reinforced responding during the extinction phase (Figure $5 \mathrm{~b}$ and $\mathrm{c}$ ). During the reinstatement tests, pretreatment with nor-BNI blocked U50,488-induced reinstatement (Figure 5d). The
ANOVA, which included the between-subjects factor of nor-BNI dose, and the within-subjects factors of U50,488 Dose and Lever, showed a significant interaction between the three factors $\left(\mathrm{F}_{1,18}=6.6, p=0.02\right)$, and an interaction between nor-BNI dose and U50,488 dose $\left(\mathrm{F}_{1,18}=8.0, p=0.01\right)$. The post hoc analyses showed that the active lever pressing of rats injected with systemic U50,488 and BNST vehicle was significantly higher than those injected with systemic U50,488 and BNST nor-BNI $(p=0.03)$. These results indicate that activation of KORs in BNST is critical to U50,488-induced reinstatement of alcohol seeking.

\section{BNST Injections of U50,488 Reinstate Alcohol Seeking}

The goal of Exp. 4 was to determine the sufficiency of activation of BNST KORs in inducing reinstatement. To test this idea, we determined whether BNST injections of U50,488 would mimic the drug's systemic effect on reinstatement (see Figure 6a for experimental timeline). As in Exp. 1-3, the rats demonstrated reliable alcohol selfadministration and extinction of the alcohol-reinforced responding during the extinction phase (Figure $6 \mathrm{~b}$ and $\mathrm{c}$ ). BNST injections of U50,488 modestly reinstated alcohol seeking (Figure 6d). The ANOVA, which included the within-subjects factors of U50,488 Dose and Lever, showed a significant U50,488 Dose $\times$ Lever interaction $\left(F_{3,27}=3.7\right.$ $p=0.03$ ). Active lever pressing after injections of the high dose of U50,488 ( $3 \mu \mathrm{g} /$ side) was significantly higher than the vehicle and the lower doses ( $p$-values $<0.05)$. These results indicate that agonist activation of BNST KORs is sufficient to induce modest reinstatement of alcohol seeking.

\section{BNST Injections of Nor-BNI Had a Minimal Effect on High-Rate Operant Responding for Food}

The goal of Exp. 5 was to rule out the possibility that BNST nor-BNI injections blocked U50,488-induced reinstatement of alcohol seeking (Exp. 3) because of nonspecific motor deficits. To test this possibility, we determined the effects of nor-BNI BNST injections on high-rate lever pressing for palatable food pellets (Supplementary Figure S1a and b). We found that BNST nor-BNI injections $(4 \mu \mathrm{g} / \mathrm{side})$ had a modest, statistically nonsignificant effect on lever pressing for the food pellets (Supplementary Figure S1c). The statistical analysis, which included the within-subjects factors of nor-BNI Dose and Lever, showed a significant effect of Lever $\left(F_{1,9}=49.7, p=0.001\right)$ but no effect of nor-BNI dose or an interaction between the two factors. These results indicate that the BNST injection of nor-BNI did not reduce U50,488induced reinstatement of alcohol seeking (Exp. 3) by causing nonspecific motor deficits.

\section{Systemic Injections of U50,488 Increased Plasma Corticosterone Levels}

The goal of Exp. 6 was to determine whether under our experimental conditions, the effective dose of U50,488 for reinstatement of alcohol seeking induces a physiological stress response, as assessed by measuring plasma levels of the stress hormone corticosterone (Marinelli and Piazza, 2002; Marinelli et al, 1997). We found that systemic injections of U50,488 (5 mg/kg) increased plasma corticosterone levels: 
0 min after injection (baseline condition): $257.7 \pm 37.4 \mathrm{ng} / \mathrm{ml}$; $30 \mathrm{~min}$ after injection: $584.5 \pm 57.8 \mathrm{ng} / \mathrm{ml}$; and $60 \mathrm{~min}$ after injection: $447.5 .5 \pm 41.6 \mathrm{ng} / \mathrm{ml}$. The statistical analysis showed a main effect of Time after injection $\left(\mathrm{F}_{2,27}=12.5\right.$, $p=0.001)$. Corticosterone levels were significantly higher in the $30 \mathrm{~min}(p=0.001)$ or $60 \mathrm{~min} \quad(p=0.008)$ groups a

dmPFC, vmPFC and OFC

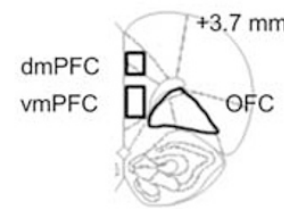

b

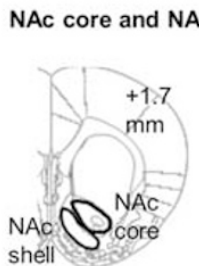

d
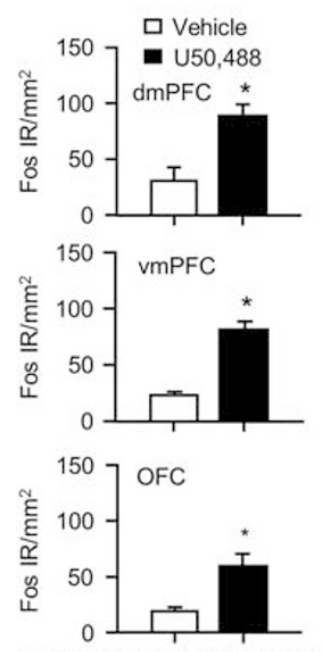

e

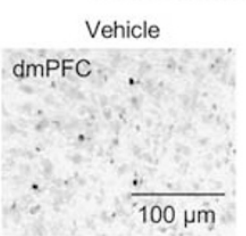

U 50,488
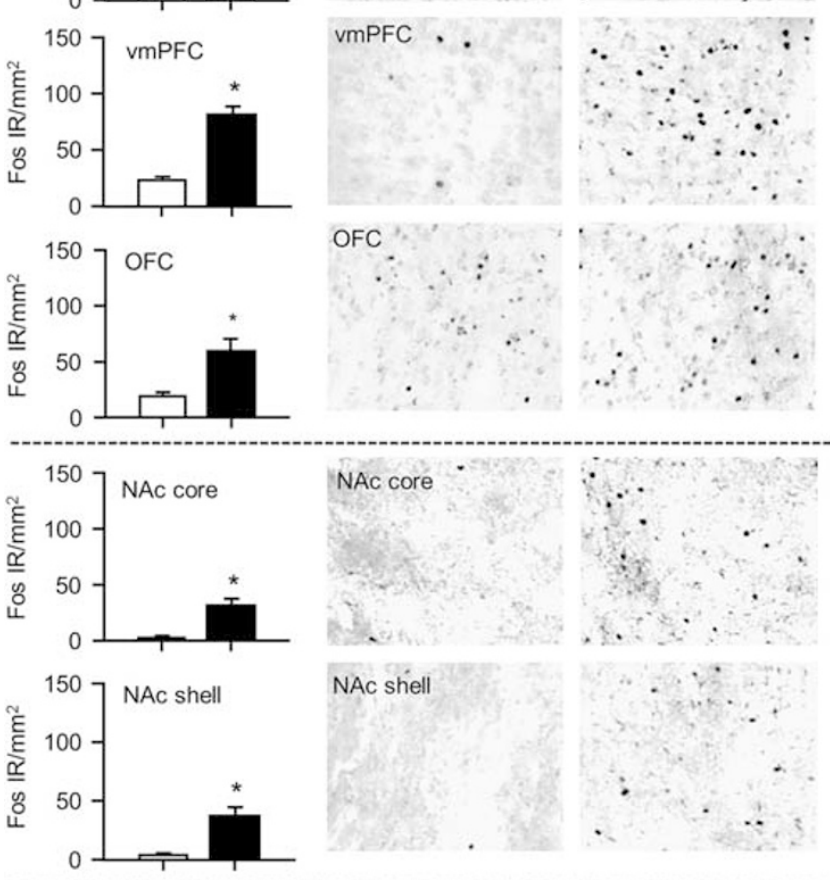

NAc shell
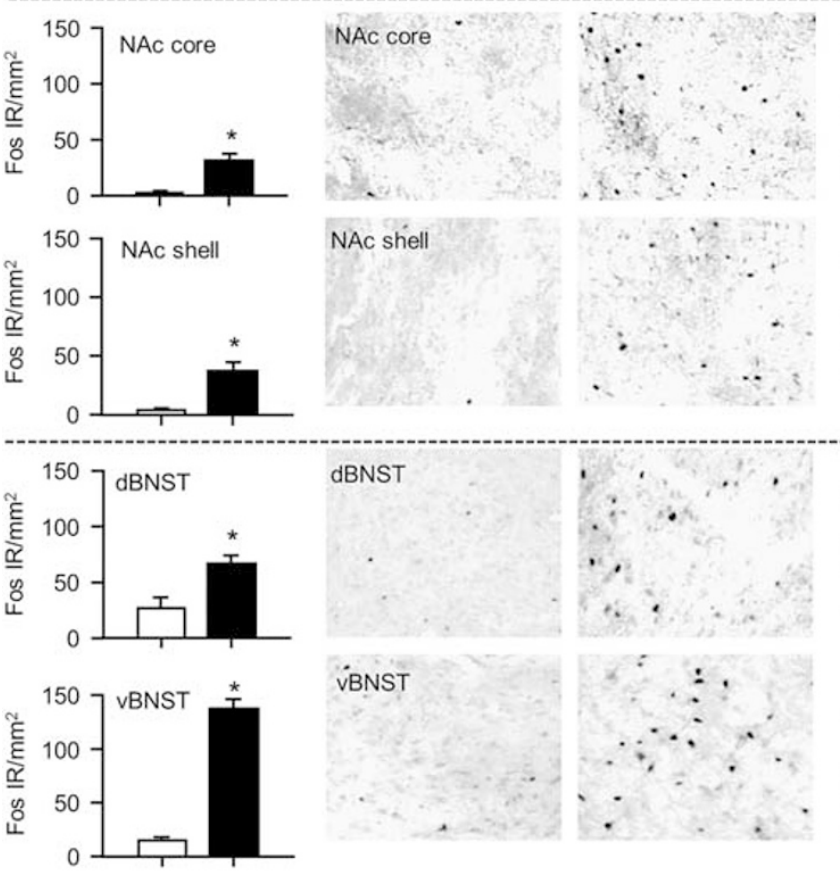

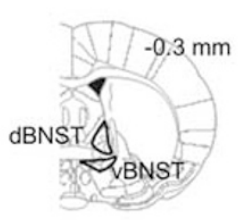

f
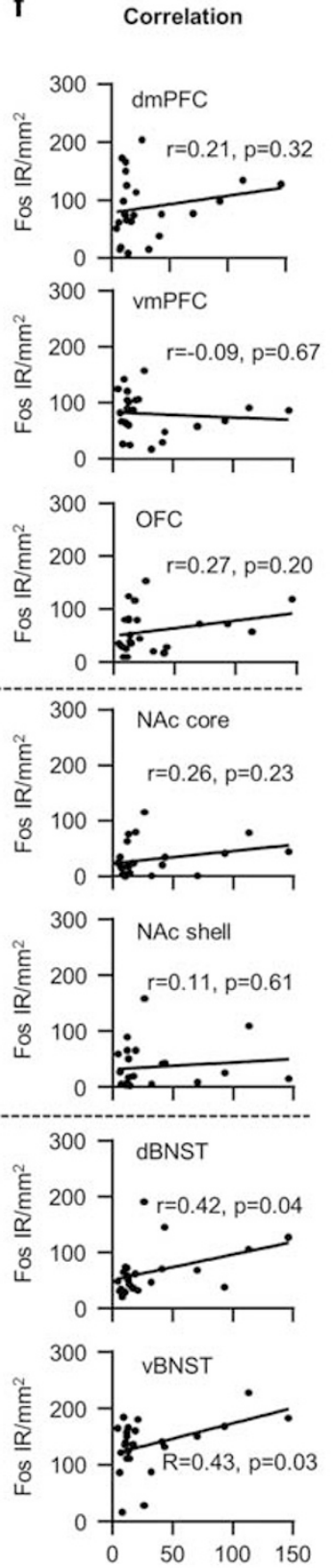

Active lever presses $(1 \mathrm{~h})$

Figure 3 U50,488-induced reinstatement of alcohol seeking is associated with increased neuronal activity in dorsal and ventral mPFC, OFC, NAc, and BNST (Exp. 2). (a-c) Sampling region of the different brain areas (Paxinos and Watson, 2005). (d) Mean \pm SEM Fos-labeled neurons in rats injected with vehicle or U50,488 (5 mg/kg, i.p.). (e) Representative photomicrographs of Fos expression from rats treated with vehicle or U50,488 (scale bar $=100 \mathrm{\mu m}$ ). (f) Pearson's $r$ correlations of Fos expression in the different brain areas with active lever pressing in rats injected with U50,488. *Different from vehicle, $p<0.05$. Vehicle, $n=6-8$ per brain area; U50,488, $n=23-24$ per brain area. dmPFC, dorsal mPFC; vmPFC, ventral mPFC; dBNST, dorsal BNST; vBNST, ventral BNST. 
a

CeA, BLA and LH

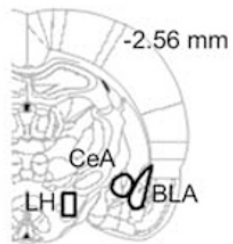

b

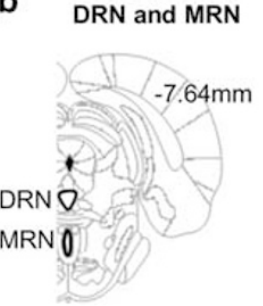

c

NTS

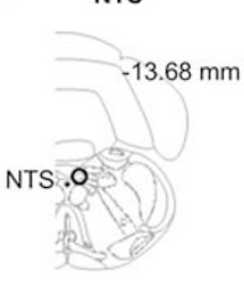

d

Grouped Fos data
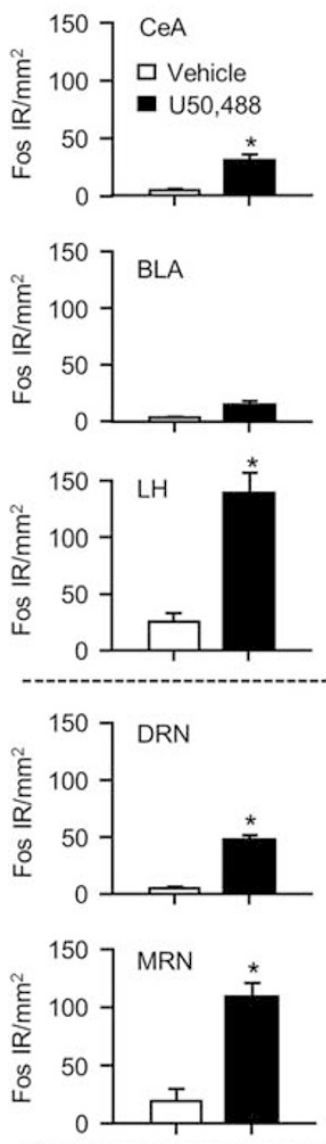

e

Representative Fos images Vehicle

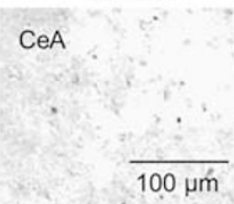

BLA
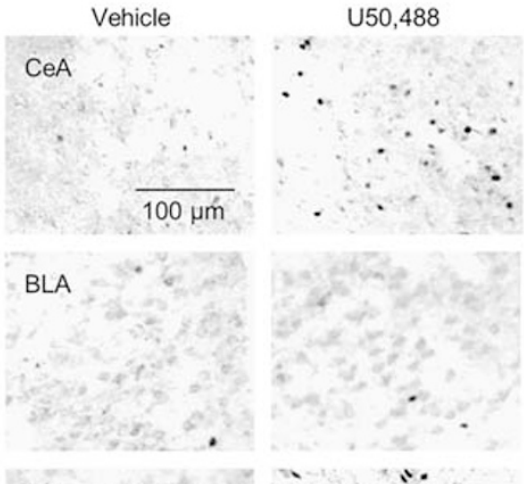

f

\section{Correlation}
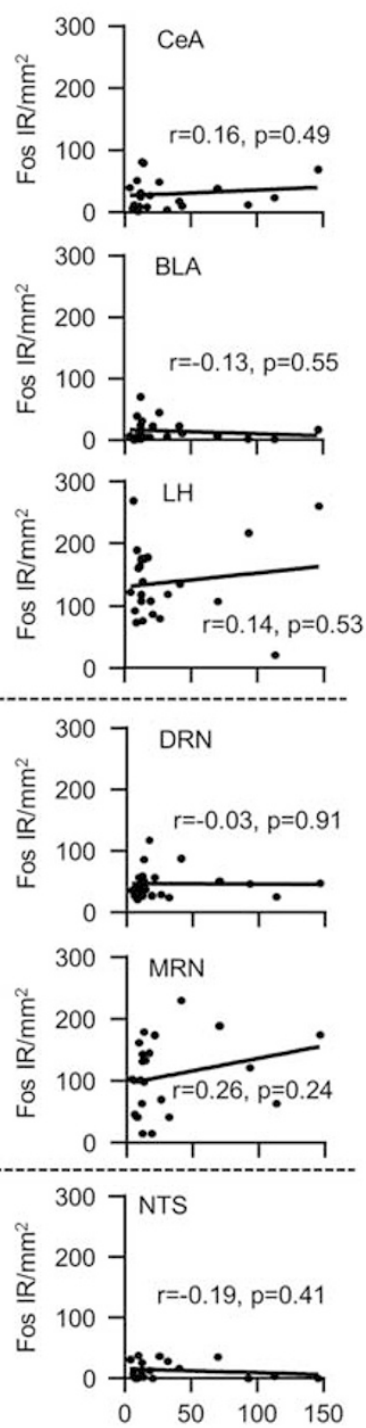

Active lever presses (1 $\mathrm{h})$

Figure 4 U50,488-induced reinstatement of alcohol seeking is associated with increased neuronal activity in the CeA, LH, DRN, MRN, and NTS, but not BLA (Exp. 2). (a-c) Sampling region of the different brain areas (Paxinos and Watson, 2005). (d) Mean \pm SEM Fos-labeled neurons in rats injected with vehicle or U50,488 (5 mg/kg, i.p.). (e) Representative photomicrographs of Fos expression from rats treated with vehicle or U50,488 (scale bar $=100 \mu \mathrm{m}$ ). ( $f$ ) Pearson's $r$ correlations of Fos expression in the different brain areas with active lever presses in rats injected with U50,488. *Different from vehicle, $p<0.05$. Vehicle, $n=7-8$ per brain area; U50,488, $n=21-24$ per brain area.

compared with the 0 min group. These results indicate that a U50,488 dose $(5 \mathrm{mg} / \mathrm{kg})$ that induces reinstatement of alcohol seeking also induces a physiological stress response, as indicated by increased plasma corticosterone.

\section{DISCUSSION}

In a previous study, we found that systemic injections of U50,488 reinstate alcohol seeking after extinction (Funk et al, 2014). The goal of our present study was first to 
Timeline: Experiment 3
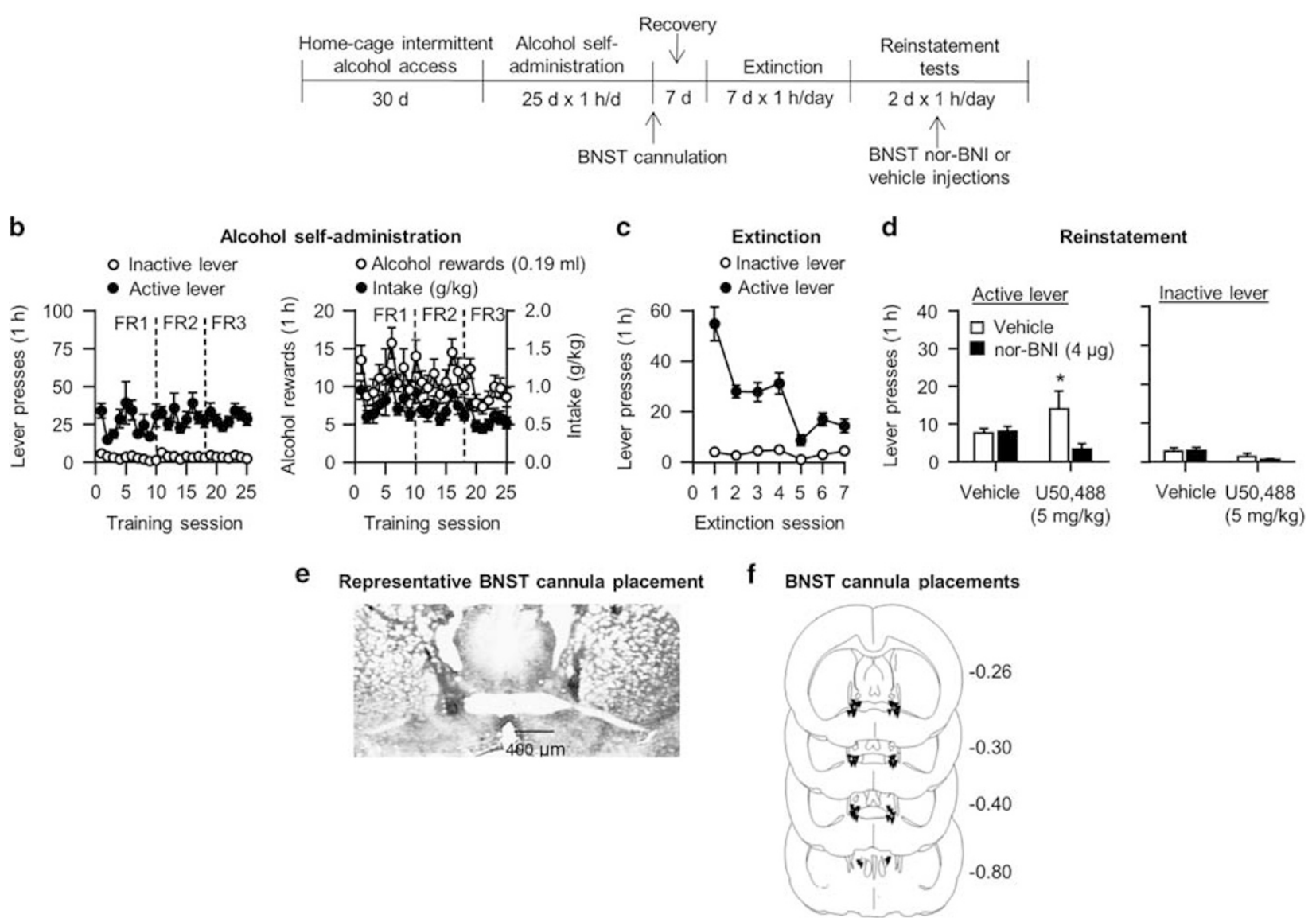

Figure 5 Nor-BNI injections into the BNST blocked U50,488-induced alcohol seeking (Exp. 3). (a) Timeline of the experiment. (b) Self-administration: mean \pm SEM number of active and inactive lever presses (left) and alcohol rewards and $\mathrm{g} / \mathrm{kg}$ intake (right) during the 25 training sessions. (c) Extinction: mean \pm SEM number of non-reinforced presses on the previously active lever and on the inactive lever during the 7 extinction days. (d) Reinstatement: mean \pm SEM number of non-reinforced presses on the previously active lever and on the inactive lever during the reinstatement tests. We injected the rats with vehicle or nor-BNI $(4 \mu \mathrm{g} / 0.5 \mu \mathrm{l} / \mathrm{side})$ into the BNST and I $5 \mathrm{~min}$ later with U50,488 (5 mg/ $/ \mathrm{kg}$, i.p.); we started the test session $30 \mathrm{~min}$ after the U50,488 injection. (e) Representative cannula placements in the BNST. Scale bar $=400 \mu \mathrm{m}$. (f) Cannula placements: numbers represent mm from bregma (Paxinos and Watson, 2005). *Different from vehicle, $p<0.05, n=9-1$ I/group. FR, fixed ratio.

independently replicate this finding, and then to explore brain mechanisms of U50,488-induced reinstatement by using the activity marker Fos and site-specific injections of the selective KOR antagonist nor-BNI and U50,488. The four main findings of our study are: (1) U50,488-induced reinstatement was associated with increased Fos expression in several cortical and subcortical brain areas, (2) U50,488induced reinstatement was correlated with Fos expression in dorsal and ventral BNST but not in the other brain areas, (3) pretreatment with BNST injections of nor-BNI blocked U50,488-induced reinstatement, and (4) BNST injections of U50,488 partially mimicked the drug's systemic effect on reinstatement. These results indicate that KORs in the BNST, a region implicated in stress responses and stress-induced reinstatement of drug seeking (Mantsch et al, 2016; Silberman and Winder, 2013), are critical to U50,488induced reinstatement of alcohol seeking.

\section{Methodological and Interpretational Considerations}

Several methodological issues should be considered in the interpretation of the inhibitory effect of BNST nor-BNI injections on U50,488-induced reinstatement of alcohol seeking. The first issue is that the effect of these injections on reinstatement might be due to diffusion into the nearby ventricles and actions on KORs in distal brain areas (Johnson and Epstein, 1975). Although we cannot rule out this possibility, we believe that it is unlikely, because we implanted the cannulas at a $15^{\circ}$ angle to avoid penetrating the ventricles (Figure 5e).

The second issue is the degree to which the effect of norBNI on U50,488-induced reinstatement is mediated by KORs after acute injections $45 \mathrm{~min}$ before the reinstatement tests. In this regard, although nor-BNI is a prototypical and widely used selective KOR antagonist (Portoghese et al, 1987), there are reports that the drug also binds to $\mu$-opioid receptors (MORs) for several hours after systemic injections (Broadbear et al, 1994; Endoh et al, 1992), but see Narita et al (1993) for pharmacological data that do not support MOR-mediated effects of acute nor-BNI. In addition, Harshberger et al (2016) recently reported that systemic injections of a high dose $(3 \mathrm{mg} / \mathrm{kg}$, s.c.) of the preferential MOR antagonist naltrexone decreased U50,488-induced reinstatement of alcohol seeking. However, the data from 
Timeline: Experiment 4

\begin{tabular}{|c|c|c|c|c|}
$\begin{array}{c}\text { Limited } \\
\text { alcohol access }\end{array}$ & $\begin{array}{c}\text { Alcohol self- } \\
\text { administration }\end{array}$ & $\begin{array}{c}\text { Recovery } \\
\downarrow\end{array}$ & Extinction & $\begin{array}{c}\text { Reinstatement } \\
\text { tests }\end{array}$ \\
\hline $17 \mathrm{~d} \times 30 \mathrm{~min} / \mathrm{d}$ & $23 \mathrm{~d} \times 1 \mathrm{~h} / \mathrm{d}$ & $7 \mathrm{~d}$ & $7 \mathrm{~d} \times 1 \mathrm{~h} / \mathrm{day}$ & $4 \mathrm{~d} \times 1 \mathrm{~h} /$ day \\
& \multicolumn{2}{|c|}{$\uparrow^{\text {BNST cannulation }}$} & $\begin{array}{c}\text { BNST U50,488 or } \\
\text { vehicle injections }\end{array}$
\end{tabular}
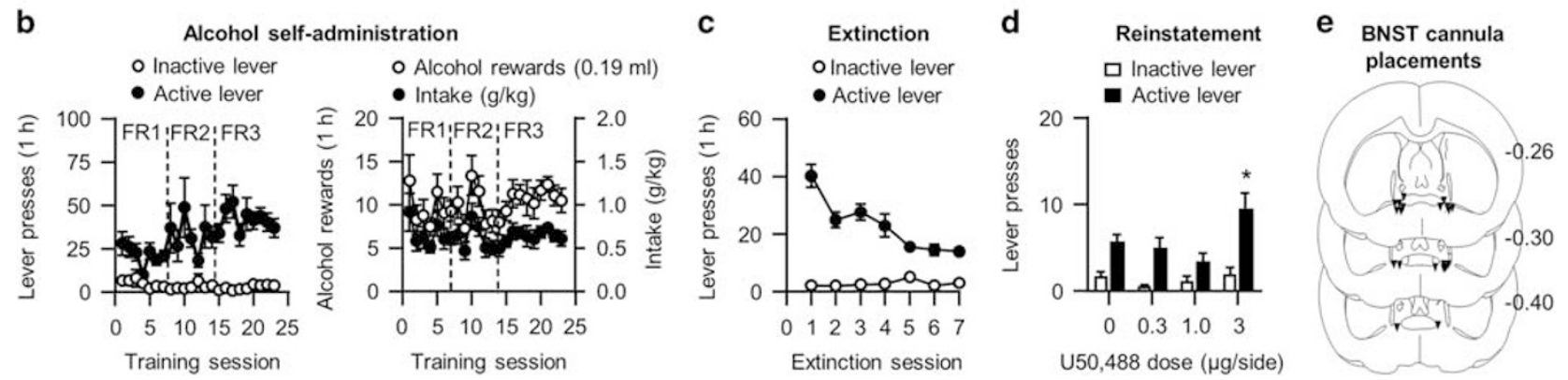

Figure 6 U50,488 injections into the BNST reinstated alcohol seeking (Exp. 4). (a) Timeline of the experiment. (b) Self-administration: mean \pm SEM number of active and inactive lever presses (left) and alcohol rewards and g/kg intake (right) during the 23 training sessions. (c) Extinction: mean \pm SEM number of nonreinforced presses on the previously active lever and on the inactive lever during the 7 extinction sessions. (d) Reinstatement: mean \pm SEM number of nonreinforced presses on the previously active lever and on the inactive lever during the reinstatement tests. We injected the rats with vehicle or U50,488 (0.3, I, $3 \mu \mathrm{g} / 0.5 \mu \mathrm{l} / \mathrm{side}$ ) into the BNST and started the session $5 \mathrm{~min}$ later. (e) Cannula placements: numbers represent mm from bregma (Paxinos and Watson, 2005). *Different from vehicle, $p<0.05, n=10$. FR, fixed ratio.

this study are difficult to interpret, because U50,488 had a very weak effect on reinstatement (less than 10 lever presses during the test sessions). In addition, naltrexone has a moderate affinity for KORs and at high doses will block these receptors (Goldstein and Naidu, 1989). Thus, a likely interpretation of the results of Harshberger et al (2016) is that naltrexone blocked U50,488-induced reinstatement because of inhibition of KORs. Together, based on the pharmacological selectivity of both U50,488 (Clark and Pasternak, 1988; de Costa et al, 1990) and nor-BNI (Portoghese et al, 1987) for KORs, the most parsimonious pharmacological interpretation of our data is that the effect of BNST nor-BNI injections on U50,488-induced reinstatement is mediated by local blockade of KORs.

Another issue is the modest and non-dose-dependent effect of BNST U50,488 injections on reinstatement that was weaker and less robust than the drug's systemic effect. The reasons for these different results are unknown and we cannot rule out that they are partly due to different alcohol training conditions between Exp. 3 and 4 (see Supplementary Material Online). Another possibility is that U50,488induced reinstatement is caused by coordinated activation of KORs in BNST and other brain areas like the amygdala (Nygard et al, 2016). However, empirical evidence inconsistent with this idea is that BNST nor-BNI injections completely blocked the systemic effect of U50,488 on reinstatement (Exp. 3). It is also possible that U50,488 doses of $>3 \mu \mathrm{g} /$ side would have elicited a stronger reinstatement of alcohol seeking.

Another issue to consider in the interpretation of our data within the context of the general phenomenon of stressinduced reinstatement (Mantsch et al, 2016; Shaham et al, $2000 \mathrm{~b}$ ) is whether the effect of U50,488 on reinstatement of alcohol seeking is due to the instigation of a stress-like state that promotes drug seeking. In support of this notion, we found that, as with exposure to environmental stressors like footshock or restraint (Kant et al, 1985; Shaham et al, 1997), U50,488 injections increased plasma levels of the stress hormone corticosterone (Selye, 1936). However, the observation that a pharmacological agent increases corticosterone does not necessary imply that the hormonal response will be followed by a behavioral and psychological stress state that laboratory animals or humans will avoid (Chen et al, 2015; Marinelli and Piazza, 2002; Piazza et al, 1993). For example, psychostimulants, opioids, and alcohol reliably increase plasma corticosterone levels in rodents (Piazza and Le Moal, 1997; 1998,; Sarnyai et al, 2001). Nevertheless, based on the literature, it is highly likely that $5 \mathrm{mg} / \mathrm{kg}$ of U50,488 induces stress-like aversive behavioral and psychological effects, because it is well established that like external stressors, U50,488 causes CPA (Ehrich et al, 2015; Land et al, 2008; Mucha and Herz, 1985; Mucha et al, 1985) and anxiety- and depressive-like responses in rodent models of anxiety and depression (Mague et al, 2003; Todtenkopf et al, 2004; Valdez and Harshberger, 2012).

\section{Role of the BNST in Reinstatement of Drug Seeking}

To the degree that U50,488 is a pharmacological stressor that induces a stress-like state, our study appears to provide novel evidence for a role of the BNST in stress-induced reinstatement of alcohol seeking. These data agree with results from prior studies on the role of BNST in stress-induced reinstatement of opiate and psychostimulant seeking and preference in the self-administration and CPP versions of the reinstatement model (Erb et al, 2001; Mantsch et al, 2016).

Thus, inhibition of CRF or noradrenaline neurotransmission in the BNST decreases footshock stress-induced reinstatement of cocaine seeking (Erb and Stewart, 1999; Leri et al, 2002; Vranjkovic et al, 2014) and morphine CPP 
(Wang et al, 2001, 2006). In addition, 6-OHDA lesions of the ventral noradrenergic bundle, which innervates the BNST (Aston-Jones et al, 1999), decrease footshock-induced reinstatement of heroin seeking (Shaham et al, 2000b) and morphine CPP (Wang et al, 2001). Furthermore, reversible inactivation of the BNST with tetrodotoxin decreases footshock-induced reinstatement of heroin seeking (Shaham et al, 2000a), and reversible inactivation of the BNST with lidocaine decreases swim stress-induced reinstatement of cocaine CPP (Briand et al, 2010). However, the tetrodotoxin and lidocaine data described above should be interpreted with caution, because both drugs also inhibit neuronal activity of fibers of passage. There is also evidence that reversible inactivation of the BNST with muscimol +baclofen decreases footshock-induced reinstatement of cocaine seeking (McFarland et al, 2004) and yohimbineinduced potentiation of cue-induced cocaine seeking (Buffalari and See, 2010). However, the relevance of the results with yohimbine to the role of BNST in stress-induced reinstatement is unclear, because yohimbine's effects on operant responding during reinstatement testing appear to be independent of the history of contingent drug selfadministration and may not be related to the commonly assumed stress-like effects of yohimbine (Chen et al, 2015).

In our previous study, we found that the CRF1 receptor antagonist antalarmin decreases U50,488-induced reinstatement of alcohol seeking (Funk et al, 2014). Similarly, in squirrel monkeys, the CRF1 receptor antagonist CP-154526 decreases spiradoline (a KOR agonist)-induced reinstatement of cocaine seeking (Valdez et al, 2007). Based on these results, and the findings described above on the role of BNST $\mathrm{CRF}$ in stress-induced reinstatement of drug seeking, we speculate that U50,488-induced activation of BNST CRF neurotransmission plays a role in U50,488-induced reinstatement. Anatomical support for this notion is that the BNST receives dynorphin/CRF projections from the CeA (Marchant et al, 2007; Sakanaka et al, 1986).

Finally, previous studies have shown that KORs in BLA, $\mathrm{CeA}, \mathrm{NAc}$, and DRN play a role in nicotine, cocaine, methamphetamine, and alcohol seeking and preference (Kissler and Walker, 2016; Land et al, 2009; Nygard et al, 2016; Whitfield et al, 2015). We extend these findings by showing that BNST KORs play an important role in reinstatement of alcohol seeking. Based on our Fos data showing that U50,488 injections increased neuronal activity in the above brain areas and in others, a question for future research is whether KORs in other brain areas also play a role in reinstatement of alcohol seeking induced by U50,488 and other stressors. In this regard, KORs have an important regulatory role in the $\mathrm{BLA}$ and $\mathrm{CeA}$ projections to the BNST (Crowley et al, 2016; Li et al, 2012) and there is evidence that these projections play a role in anxiogenic (stress) responses (Crowley et al, 2016). In addition, the CeA sends dynorphinand CRF-containing projections to the BNST (Beckerman and Glass, 2012; Beckerman et al, 2013; Marchant et al, 2007). Thus, a question for future research is whether these amygdala-BNST dynorphin projections also play a role in reinstatement of alcohol seeking induced by U50,488 and other stressors.

\section{Concluding Remarks}

Our results provide new evidence for a role of the BNST in reinstatement of alcohol seeking induced by an aversive pharmacological stimulus, extending results from previous studies on the critical role of the BNST in stress-induced reinstatement of psychostimulant and opioid seeking (Mantsch et al, 2016; Shaham et al, 2000a). Our data also extend previous results on the important role of the KOR/ dynorphin system in reinstatement of drug seeking and preference (Bruchas et al, 2010; Nygard et al, 2016; Smith et al, 2012), as well as alcohol self-administration and withdrawal states (Berger et al, 2013; Kissler et al, 2014; Walker et al, 2011; Wee and Koob, 2010).

\section{FUNDING AND DISCLOSURE}

The authors declare no conflict of interest.

\section{ACKNOWLEDGMENTS}

We are grateful for the generous gifts of U50,488 and norBNI from the NIDA drug supply program. The study was supported by NIAAA-NIH funds to ADL (R01-AA024341). The writing of the paper was also supported in part by the Intramural Research Program of NIDA to the Neurobiology of Relapse Section (PI: YS).

\section{REFERENCES}

Aston-Jones G, Delfs JM, Druhan J, Zhu Y (1999). The bed nucleus of the stria terminalis: a target site for noradrenergic actions in opiate withdrawal. Ann NY Acad Sci 877: 486-498.

Beardsley PM, Howard JL, Shelton KL, Carroll FI (2005). Differential effects of the novel kappa opioid receptor antagonist, JDTic, on reinstatement of cocaine-seeking induced by footshock stressors vs cocaine primes and its antidepressant-like effects in rats. Psychopharmacology (Berl) 183: 118-126.

Beardsley PM, Pollard GT, Howard JL, Carroll FI (2010). Effectiveness of analogs of the kappa opioid receptor antagonist (3R)-7-hydroxy-N((1S)-1-\{[(3R,4R)-4-(3-hydroxyphenyl)-3,4-dimethyl-1-pipe ridinyl] methyl\}-2-methylpropyl)-1,2,3,4-tetrahydro-3-isoquinolinecarboxami de (JDTic) to reduce U50,488-induced diuresis and stress-induced cocaine reinstatement in rats. Psychopharmacology (Berl) 210: 189-198.

Bechara A, van der Kooy D (1987). Kappa receptors mediate the peripheral aversive effects of opiates. Pharmacol Biochem Behav 28: 227-233.

Beckerman MA, Glass MJ (2012). The NMDA-NR1 receptor subunit and the mu-opioid receptor are expressed in somatodendritic compartments of central nucleus of the amygdala neurons projecting to the bed nucleus of the stria terminalis. Exp Neurol 234: 112-126.

Beckerman MA, Van Kempen TA, Justice NJ, Milner TA, Glass MJ (2013). Corticotropin-releasing factor in the mouse central nucleus of the amygdala: ultrastructural distribution in NMDANR1 receptor subunit expressing neurons as well as projection neurons to the bed nucleus of the stria terminalis. Exp Neurol 239: 120-132.

Berger AL, Williams AM, McGinnis MM, Walker BM (2013). Affective cue-induced escalation of alcohol self-administration and increased $22-\mathrm{kHz}$ ultrasonic vocalizations during alcohol withdrawal: role of kappa-opioid receptors. Neuropsychopharmacology 38: 647-654. 
Bossert JM, Marchant NJ, Calu DJ, Shaham Y (2013). The reinstatement model of drug relapse: recent neurobiological findings, emerging research topics, and translational research. Psychopharmacology (Berl) 229: 453-476.

Briand LA, Vassoler FM, Pierce RC, Valentino RJ, Blendy JA (2010). Ventral tegmental afferents in stress-induced reinstatement: the role of cAMP response element-binding protein. J Neurosci 30: 16149-16159.

Broadbear JH, Negus SS, Butelman ER, de Costa BR, Woods JH (1994). Differential effects of systemically administered norbinaltorphimine (nor-BNI) on kappa-opioid agonists in the mouse writhing assay. Psychopharmacology (Berl) 115: 311-319.

Brown SA, Vik PW, Patterson TL, Grant I, Schuckit MA (1995). Stress, vulnerability and adult alcohol relapse. J Stud Alcohol 56: 538-545.

Bruchas MR, Land BB, Chavkin C (2010). The dynorphin/kappa opioid system as a modulator of stress-induced and pro-addictive behaviors. Brain Res 1314: 44-55.

Buffalari DM, See RE (2010). Inactivation of the bed nucleus of the stria terminalis in an animal model of relapse: effects on conditioned cue-induced reinstatement and its enhancement by yohimbine. Psychopharmacology (Berl) 213: 19-27.

Calu DJ, Chen YW, Kawa AB, Nair SG, Shaham Y (2014). The use of the reinstatement model to study relapse to palatable food seeking during dieting. Neuropharmacology 76 Pt B: 395-406.

Chen YW, Fiscella KA, Bacharach SZ, Tanda G, Shaham Y, Calu DJ (2015). Effect of yohimbine on reinstatement of operant responding in rats is dependent on cue contingency but not food reward history. Addict Biol 20: 690-700.

Clark JA, Pasternak GW (1988). U50,488: a kappa-selective agent with poor affinity for mul opiate binding sites. Neuropharmacology 27: 331-332.

Crowley NA, Bloodgood DW, Hardaway JA, Kendra AM, McCall JG, Al-Hasani R et al (2016). Dynorphin controls the gain of an amygdalar anxiety circuit. Cell Rep 14: 2774-2783.

Curran T, Morgan JI (1995). Fos: an immediate-early transcription factor in neurons. J Neurobiol 26: 403-412.

Dallman MF, Akana SF, Levin N, Walker CD, Bradbury MJ, Suemaru S et al (1995). Corticosteroids and the control of function in the hypothalamo-pituitary-adrenal (HPA) axis. Ann NY Acad Sci 746: 22-31.

de Costa BR, Rothman RB, Bykov V, Band L, Pert A, Jacobson AE et al (1990). Probes for narcotic receptor mediated phenomena. 17. Synthesis and evaluation of a series of trans-3,4-dichloro$\mathrm{N}$-methyl-N-[2-(1-pyrrolidinyl)cyclohexyl]benzeneacet amide $(\mathrm{U} 50,488)$ related isothiocyanate derivatives as opioid receptor affinity ligands. J Med Chem 33: 1171-1176.

Ehrich JM, Messinger DI, Knakal CR, Kuhar JR, Schattauer SS, Bruchas MR et al (2015). Kappa opioid receptor-induced aversion requires p38 MAPK activation in VTA dopamine neurons. J Neurosci 35: 12917-12931.

Endoh T, Matsuura H, Tanaka C, Nagase H (1992). Norbinaltorphimine: a potent and selective kappa-opioid receptor antagonist with long-lasting activity in vivo. Arch Int Pharmacodyn Ther 316: 30-42.

Erb S, Shaham Y, Stewart J (2001). Stress-induced relapse to drug seeking in the rat: Role of the bed nucleus of the stria terminalis and amygdala. Stress 4: 289-303.

Erb S, Stewart J (1999). A role for the bed nucleus of the stria terminalis, but not the amygdala, in the effects of corticotropinreleasing factor on stress-induced reinstatement of cocaine seeking. J Neurosci 19: RC35.

Falcon E, Maier K, Robinson SA, Hill-Smith TE, Lucki I (2015). Effects of buprenorphine on behavioral tests for antidepressant and anxiolytic drugs in mice. Psychopharmacology (Berl) 232: 907-915.

Funk D, Coen K, Le AD (2014). The role of kappa opioid receptors in stress-induced reinstatement of alcohol seeking in rats. Brain Behav 4: 356-367.
Goldstein A, Naidu A (1989). Multiple opioid receptors: ligand selectivity profiles and binding site signatures. Mol Pharmacol 36: 265-272.

Grella SL, Funk D, Coen K, Li Z, Le AD (2014). Role of the kappaopioid receptor system in stress-induced reinstatement of nicotine seeking in rats. Behav Brain Res 265: 188-197.

Harshberger E, Gilson EA, Gillett K, Stone JH, El Amrani L, Valdez GR (2016). nor-BNI antagonism of kappa opioid agonistinduced reinstatement of ethanol-seeking behavior. J Addict 2016: 1084235.

Ignar DM, Kuhn CM (1990). Effects of specific mu and kappa opiate tolerance and abstinence on hypothalamo-pituitary-adrenal axis secretion in the rat. J Pharmacol Exp Ther 255: 1287-1295.

Jackson KJ, McLaughlin JP, Carroll FI, Damaj MI (2012). Effects of the kappa opioid receptor antagonist, norbinaltorphimine, on stress and drug-induced reinstatement of nicotine-conditioned place preference in mice. Psychopharmacology (Berl) 226: 763-768.

Johnson AK, Epstein AN (1975). The cerebral ventricles as the avenue for the dipsogenic action of intracranial angiotensin. Brain Res 86: 399-418.

Kant GJ, Eggleston T, Landman-Rorbers L, Kenion CC, Driver GC, Meyerhoff JL (1985). Habituation to repeated stress is stressor specific. Pharmacol Biochem Behav 22: 631-634.

Karkhanis AN, Rose JH, Weiner JL, Jones SR (2016). Early-life social isolation stress increases kappa opioid receptor responsiveness and downregulates the dopamine system. Neuropsychopharmacology 41: 2263-2274.

Kissler JL, Sirohi S, Reis DJ, Jansen HT, Quock RM, Smith DG et al (2014). The one-two punch of alcoholism: role of central amygdala dynorphins/kappa-opioid receptors. Biol Psychiatry 75: $774-782$.

Kissler JL, Walker BM (2016). Dissociating motivational from physiological withdrawal in alcohol dependence: role of central amygdala kappa-opioid receptors. Neuropsychopharmacology 41: 560-567.

Land BB, Bruchas MR, Lemos JC, Xu M, Melief EJ, Chavkin C (2008). The dysphoric component of stress is encoded by activation of the dynorphin kappa-opioid system. J Neurosci 28: 407-414.

Land BB, Bruchas MR, Schattauer S, Giardino WJ, Aita M, Messinger D et al (2009). Activation of the kappa opioid receptor in the dorsal raphe nucleus mediates the aversive effects of stress and reinstates drug seeking. Proc Natl Acad Sci USA 106: 19168-19173.

Le A, Shaham Y (2002). Neurobiology of relapse to alcohol in rats. Pharmacol Ther 94: 137-156.

Le AD, Funk D, Harding S, Juzytsch W, Fletcher PJ, Shaham Y (2006). Effects of dexfenfluramine and 5-HT3 receptor antagonists on stress-induced reinstatement of alcohol seeking in rats. Psychopharmacology (Berl) 186: 82-92.

Le AD, Funk D, Juzytsch W, Coen K, Navarre BM, Cifani C et al (2011). Effect of prazosin and guanfacine on stress-induced reinstatement of alcohol and food seeking in rats. Psychopharmacology (Berl) 218: 89-99.

Le AD, Harding S, Juzytsch W, Funk D, Shaham Y (2005). Role of alpha-2 adrenoceptors in stress-induced reinstatement of alcohol seeking and alcohol self-administration in rats. Psychopharmacology (Berl) 179: 366-373.

Leri F, Flores J, Rodaros D, Stewart J (2002). Blockade of stressinduced, but not cocaine-induced reinstatement, by infusion of noradrenergic antagonists into the bed nucleus of the stria terminalis or the central nucleus of the amygdala. J Neurosci 22: 5713-5718.

Li C, Pleil KE, Stamatakis AM, Busan S, Vong L, Lowell BB et al (2012). Presynaptic inhibition of gamma-aminobutyric acid release in the bed nucleus of the stria terminalis by kappa opioid receptor signaling. Biol Psychiatry 71: 725-732. 
Mague SD, Pliakas AM, Todtenkopf MS, Tomasiewicz HC, Zhang Y, Stevens WC Jr et al (2003). Antidepressant-like effects of kappa-opioid receptor antagonists in the forced swim test in rats. J Pharmacol Exp Ther 305: 323-330.

Mantsch JR, Baker DA, Funk D, Le AD, Shaham Y (2016). Stressinduced reinstatement of drug seeking: 20 years of progress. Neuropsychopharmacology 41: 335-356.

Mantsch JR, Vranjkovic O, Twining RC, Gasser PJ, McReynolds JR, Blacktop JM (2014). Neurobiological mechanisms that contribute to stress-related cocaine use. Neuropharmacology 76 Pt B: 383-394.

Marchant NJ, Densmore VS, Osborne PB (2007). Coexpression of prodynorphin and corticotrophin-releasing hormone in the rat central amygdala: evidence of two distinct endogenous opioid systems in the lateral division. J Comp Neurol 504: 702-715.

Marinelli M, Piazza PV (2002). Interaction between glucocorticoid hormones, stress and psychostimulant drugs. Eur J Neurosci 16: 387-394.

Marinelli M, Rouge-Pont F, Deroche V, Barrot M, De Jesus-Oliveira C, Le Moal $M$ et al (1997). Glucocorticoids and behavioral effects of psychostimulants. I: locomotor response to cocaine depends on basal levels of glucocorticoids. J Pharmacol Exp Ther 281: 1392-1400.

Marinelli PW, Funk D, Juzytsch W, Harding S, Rice KC, Shaham Y et al (2007). The CRF1 receptor antagonist antalarmin attenuates yohimbine-induced increases in operant alcohol self-administration and reinstatement of alcohol seeking in rats. Psychopharmacology (Berl) 195: 345-355.

McFarland K, Davidge SB, Lapish CC, Kalivas PW (2004). Limbic and motor circuitry underlying footshock-induced reinstatement of cocaine-seeking behavior. J Neurosci 24: 1551-1560.

McLaughlin JP, Land BB, Li S, Pintar JE, Chavkin C (2006). Prior activation of kappa opioid receptors by U50,488 mimics repeated forced swim stress to potentiate cocaine place preference conditioning. Neuropsychopharmacology 31: 787-794.

Morley JE, Elson MK, Levine AS, Shafer RB (1982). The effects of stress on central nervous system concentrations of the opioid peptide, dynorphin. Peptides 3: 901.

Mucha RF, Herz A (1985). Motivational properties of kappa and mu opioid receptor agonists studied with place and taste preference conditioning. Psychopharmacology (Berl) 86: 274-280.

Mucha RF, Millan MJ, Herz A (1985). Aversive properties of naloxone in non-dependent (naive) rats may involve blockade of central beta-endorphin. Psychopharmacology (Berl) 86: 281-285.

Nabeshima T, Katoh A, Wada M, Kameyama T (1992). Stressinduced changes in brain Met-enkephalin, Leu-enkephalin and dynorphin concentrations. Life Sci 51: 211.

Narita M, Takahashi Y, Takamori K, Funada M, Suzuki T, Misawa $M$ et al (1993). Effects of kappa-agonist on the antinociception and locomotor enhancing action induced by morphine in mice. Jpn J Pharmacol 62: 15-24.

Nygard SK, Hourguettes NJ, Sobczak GG, Carlezon WA, Bruchas MR (2016). Stress-induced reinstatement of nicotine preference requires dynorphin/kappa opioid activity in the basolateral amygdala. J Neurosci 36: 9937-9948.

Paxinos G, Watson C (2005). The Rat Brain in Stereotaxic Coordinates. Elsevier Academic Press: Amsterdam.

Piazza PV, Deroche V, Deminiere JM, Maccari S, Le Moal M, Simon H (1993). Corticosterone in the range of stress-induced levels possesses reinforcing properties: implications for sensationseeking behaviors. Proc Natl Acad Sci USA 90: 11738-11742.

Piazza PV, Le Moal M (1997). Glucocorticoids as a biological substrate of reward: physiological and pathophysiological implications. Brain Res Rev 25: 359-372.

Piazza PV, Le Moal M (1998). The role of stress in drug self-administration. Trends Pharmacol Sci 19: 67-74.

Pliakas AM, Carlson RR, Neve RL, Konradi C, Nestler EJ, Carlezon WA Jr (2001). Altered responsiveness to cocaine and increased immobility in the forced swim test associated with elevated cAMP response elementbinding protein expression in nucleus accumbens. J Neurosci 21: 7397-7403.

Portoghese PS, Lipkowski AW, Takemori AE (1987). Binaltorphimine and nor-binaltorphimine, potent and selective kappa-opioid receptor antagonists. Life Sci 40: 1287-1292.

Privette TH, Terrian DM (1995). Kappa opioid agonists produce anxiolytic-like behavior on the elevated plus-maze. Psychopharmacology (Berl) 118: 444-450.

Redila VA, Chavkin C (2008). Stress-induced reinstatement of cocaine seeking is mediated by the kappa opioid system. Psychopharmacology (Berl) 200: 59-70.

Sakanaka M, Shibasaki T, Lederis K (1986). Distribution and efferent projections of corticotropin-releasing factor-like immunoreactivity in the rat amygdaloid complex. Brain Res 382: $213-238$

Sarnyai Z, Shaham Y, Heinrichs SC (2001). The role of corticotropin-releasing factor in drug addiction. Pharmacol Rev 53: 209-244.

Schank JR, Goldstein AL, Rowe KE, King CE, Marusich JA, Wiley JL et al (2012). The kappa opioid receptor antagonist JDTic attenuates alcohol seeking and withdrawal anxiety. Addict Biol 17: 634-647.

Schlosburg JE, Whitfield TW Jr, Park PE, Crawford EF, George O, Vendruscolo LF et al (2013). Long-term antagonism of kappa opioid receptors prevents escalation of and increased motivation for heroin intake. J Neurosci 33: 19384-19392.

Selye H (1936). A syndrome produced by diverse nocuous agents. Nature 138: 32-36.

Shaham Y, Erb S, Stewart J (2000a). Stress-induced relapse to heroin and cocaine seeking in rats: a review. Brain Res Brain Res Rev 33: 13-33.

Shaham Y, Funk D, Erb S, Brown TJ, Walker CD, Stewart J (1997). Corticotropin-releasing factor, but not corticosterone, is involved in stress-induced relapse to heroin-seeking in rats. J Neurosci 17: 2605-2614.

Shaham Y, Highfield D, Delfs J, Leung S, Stewart J (2000b). Clonidine blocks stress-induced reinstatement of heroin seeking in rats: an effect independent of locus coeruleus noradrenergic neurons. Eur J Neurosci 12: 292-302.

Shaham Y, Shalev U, Lu L, De Wit H, Stewart J (2003). The reinstatement model of drug relapse: history, methodology and major findings. Psychopharmacology 168: 3-20.

Silberman Y, Winder DG (2013). Emerging role for corticotropin releasing factor signaling in the bed nucleus of the stria terminalis at the intersection of stress and reward. Front Psychiatry 4: 42.

Sinha R, Li CS (2007). Imaging stress- and cue-induced drug and alcohol craving: association with relapse and clinical implications. Drug Alcohol Rev 26: 25-31.

Smith JS, Schindler AG, Martinelli E, Gustin RM, Bruchas MR, Chavkin C (2012). Stress-induced activation of the dynorphin/ kappa-opioid receptor system in the amygdala potentiates nicotine conditioned place preference. J Neurosci 32: 1488-1495. Sperling RE, Gomes SM, Sypek EI, Carey AN, McLaughlin JP (2010). Endogenous kappa-opioid mediation of stress-induced potentiation of ethanol-conditioned place preference and selfadministration. Psychopharmacology (Berl) 210: 199-209.

Todtenkopf MS, Marcus JF, Portoghese PS, Carlezon WA Jr (2004). Effects of kappa-opioid receptor ligands on intracranial selfstimulation in rats. Psychopharmacology (Berl) 172: 463-470.

Valdez GR, Harshberger E (2012). kappa opioid regulation of anxiety-like behavior during acute ethanol withdrawal. Pharmacol Biochem Behav 102: 44-47.

Valdez GR, Platt DM, Rowlett JK, Ruedi-Bettschen D, Spealman RD (2007). Kappa agonist-induced reinstatement of cocaine seeking in squirrel monkeys: a role for opioid and stress-related mechanisms. J Pharmacol Exp Ther 323: 525-533. 
Van't Veer A, Carlezon WA Jr (2013). Role of kappa-opioid receptors in stress and anxiety-related behavior. Psychopharmacology (Berl) 229: 435-452.

Vranjkovic O, Gasser PJ, Gerndt CH, Baker DA, Mantsch JR (2014). Stress-induced cocaine seeking requires a beta-2 adrenergic receptor-regulated pathway from the ventral bed nucleus of the stria terminalis that regulates CRF actions in the ventral tegmental area. J Neurosci 34: 12504-12514.

Walker BM, Koob GF (2008). Pharmacological evidence for a motivational role of kappa-opioid systems in ethanol dependence. Neuropsychopharmacology 33: 643-652.

Walker BM, Zorrilla EP, Koob GF (2011). Systemic kappa-opioid receptor antagonism by nor-binaltorphimine reduces dependence-induced excessive alcohol self-administration in rats. Addict Biol 16: 116-119.

Wang J, Fang Q, Liu Z, Lu L (2006). Region-specific effects of brain corticotropin-releasing factor receptor type 1 blockade on footshock- stress- or drug-priming-induced reinstatement of morphine conditioned place preference in rats. Psychopharmacology 185: 19-28.

Wang X, Cen X, Lu L (2001). Noradrenaline in the bed nucleus of the stria terminalis is critical for stress-induced reactivation of morphine-conditioned place preference in rats. Eur J Pharmacol 432: 153-161.

Wee S, Koob GF (2010). The role of the dynorphin-kappa opioid system in the reinforcing effects of drugs of abuse. Psychopharmacology (Berl) 210: 121-135.

Wee S, Orio L, Ghirmai S, Cashman JR, Koob GF (2009). Inhibition of kappa opioid receptors attenuated increased cocaine intake in rats with extended access to cocaine. Psychopharmacology (Berl) 205: 565-575.

Whitfield TW Jr, Schlosburg JE, Wee S, Gould A, George O, Grant Y et al (2015). kappa Opioid receptors in the nucleus accumbens shell mediate escalation of methamphetamine intake. J Neurosci 35: 4296-4305.

Supplementary Information accompanies the paper on the Neuropsychopharmacology website (http://www.nature.com/npp) 